\title{
FL, KAKA, and the Value of Lesbian Paragrams
}

\author{
Susan Holbrook
}

En écrivant contre la critique de McCaffery portant sur bp Nichol et le paragramme, Susan Holbrook parle de la valeur des paragrammes lesbiens par le biais de la poète et romancière québécoise Nicole Brossard. Plutôt politique, mais plus sensuelle quant il s'agit de la langue, Brossard - tout comme d'autres poètes lesbiennes canadiennes - risque la langue.

Mais les hommes ont confondu l'erreur et la souffrance.

(Le Désert Mauve 83)

But men confused error with suffering.

(Mauve Desert 127)

In "The Martyrology as Paragram," Steve McCaffery subjects bp Nichol's multi-volume long poem to an analysis turning on the paragram, a figure through which the concrete resources of language are mobilized. The paragram, according to McCaffery, is characterized by "meaning's emergence out of a different meaning both of which share common graphic or acoustic components" (69). Noting the syntactic economy of McCaffery's essays, "The Martyrology as Paragram" and "Writing as a General Economy," I find that subjects, predicates and objects are configured to upset traditional notions of authorial mastery over technique, device and medium. Paragrams "inscribe," ("Paragram" 64) writing "threatens" (61), and the writing subject slips into passivity, becoming "lost, defabricated by the flow-producing agencies of homophony and the detached letter" (73).

While McCaffery's discussions of the paragram represent a crucial insistence on the concrete and polysemic potential of language, his model doesn't account for writers who maintain a ludic relationship with language, yet cannot afford to replicate the passive stance of artist-before-themuse. Lesbian feminist poet Nicole Brossard, for example, could be celebrating a paragrammatic slide when she speaks, in mécanique jongleuse suivi de masculin grammaticale, ${ }^{1}$ about "le trop plein du code déversé" (56) ("the overflow of the code spilled out" (58)). But reading her argument 
that it was after discovering she was a lesbian that her writing became more "fluid" ("Poetic Politics" 78), I question the opposition McCaffery makes between paragrammatic "sliding and slipping of meaning" ("General Economy" 208) and intention. How does Brossard's "SÉCRÉTION (au bord" (56) ("SECRETION (on the edge" (66)) inflect his "secretion ... out of semantic's ideal structure" ("Paragram" 64)? In other words, in lesbian-feminist poetry, just what (or who) are the "flow-producing" agents?

In his discussion of Bataille's "general economy," McCaffery celebrates the paragram's inauguration of a stripping of value, as it "ensure[s] that there will always be a superfluity of signifiers and a degree of waste and unrecouperability of meaning" (209). Certainly the promise of wordplay lies in its decompression of the sign and its transgression of the hierarchical values of grammar (the monopoly of Noun / Verb). But what is the value of this promise? I suggest that the notions of 'value' and 'waste' raised in McCaffery's theorizations beg salient questions which ultimately cohere around the Subject and its crisis as staged by the paragram. First of all, can a function of value ever be evaded, particularly in the context of Nichol's long poem, where certain themes, indeed values, ${ }^{2}$ are overdetermined? And doesn't obscuring value constitute a denial of what Fredric Jameson has called a "political unconscious" which is at work in Nichol's reading of his own writing? What is the cost, even - perhaps particularly - at this level of the microsyntactic, of claiming a space bereft of value?

These questions pivot around an epistemology of value, underlined by Brossard's assertion that "male psychic energy has fantasized - constituted - a corpus of 'knowledge' as to what is right and wrong, what is valued and what is not" (86). What is not valued, "waste" in other words, is determined by this epistemology in specifically misogynist ways. Witness Julia Kristeva's observation, in her philosophical / anthropological study of abjection Powers of Horror, ${ }^{3}$ that "polluting objects fall, schematically, into two types: excremental and menstrual. Neither tears nor sperm, for instance, although they belong to borders of the body, have any polluting value $^{\prime \prime}$ (71). Consider also the case of the nineteenth century French hermaphrodite Herculine Barbin who was pronounced male by physicians who invested his/her semen (devoid of spermatazoa) with a positive value they refused his/her vaginal secretions. 'Waste' and 'value' are clearly terms which are themselves sedimented in support of an androcentric value-system delineating the bounds of proper Subjecthood. 
Pushing at the horizons of the symbolic, Brossard intervenes in the standard deployments of morpheme, word, syntax with a view to shaping a language-world which 'values' women and lesbians.

In order to reinforce intentionality's dissolution in paragrammatic writing, McCaffery engages the notion of error. He argues that "intentional meaning" is continually threatened by the "errant aspects" ("Paragram" 61) inherent in language. The omnipresence of this catachrestic risk prompts me to entertain an intent to err or, more precisely, a desire to err. Desire itself, in fact, in its extension across both the conscious and unconscious, can be seen to mediate between error and intentionality. And desire reflects, and is subject to, values. Lesbian-feminist poets justify a desire to seek out the errant through their revaluing of that which is traditionally considered to be correct, to 'make sense,' to posit a unitary meaning through a transparent medium. This proper language is the idiom that Daphne Marlatt argues "misrepresents" her ("Musing with Mothertongue" 55) and Brossard contends is composed of "lies" and "fraud" ("Poetic" 75, 78). If proper, patriarchally-loaded language represents her erroneously, then the poet's corrective gestures necessarily involve breaking into the improper zone of catachresis, performing what Marlatt names "unspeakable breaches of usage" (56). Error has been revalued and inflected by voluntarism in the context of Brossard's Transformances with Daphne Marlatt ${ }^{5}$ as well as in the world of Le Désert mauve's 'auteures.' Why should The Martyrology's wordplay depend on the implicit qualifier, 'I didn't mean it'? Can't we trace a drama of value(s) through the losses/gains in the transition from "speech" to "eech" to "each" (Martyrology Book 2)?

A paragrammatic logic invites us to consider "eech" which, although invested with no morphemic value itself, leads through further translation to the word "each" in the following figure:

speech

eech to

each

A play which begins with "speech" and terminates with "to each" certainly reflects the value of human communication propelling The Martyrology and resonates with the apostrophic mode of address dominating Books 1 \& 2 ("i want to tell you a story," "saint orm you were a 
stranger," "father i am sorry"). Such a figure exemplifies the numerous paragrammatic nodes in the poem where value is immediately recuperated, instances McCaffery overlooks in his discussion of the ways Nichol contains paragrammatic waste. McCaffery notes that Nichol gets his ' $\mathrm{I}$ ' back through the "territorializing forces of reference, investment and

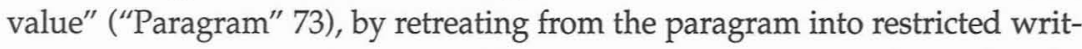
ing. I suggest that such recuperation occurs more immanently, within the paragram itself. McCaffery denies the force of intentionality in the following passage, arguing that "wordplay releases the other text as pre-logical 'emission' from the latent positions within the syntax" ("Paragram" 69):

o

$\mathrm{pq}$

r

or b d

bidet

confusion of childhood's 'kaka'

the Egyptian ' $\mathrm{KA}^{\prime}$

soul (The Martryology Book 4)

Undoubtedly, there is a compositional dynamic operant here which is processual, incorporating the shapes and sounds of text already written, but in a scramble to differentiate this from a poetics based on the intention of an expressive subject, McCaffery overstates the case for wordplay's selfpropulsion. To suggest that "Kaka' itself splits to isolate the phoneme 'ka'" (68, my emphasis) denies Nichol any agency, thus ironically collapsing the multiplicity of the "latent positions within the syntax." (Perhaps in a poem by Bob Perelman, for instance, Kaka would have split to reveal the abbreviation 'a.k.a.' ${ }^{6}$ And 'b d' on someone else's page might have produced 'body' rather than 'bidet'). McCaffery's characterization of the paragram as self-generating colludes with Nichol's passive stance (repeatedly thematized in lines such as "only the words you trust to take you through") to neutralize the passage of Kaka's 'power of horror' into the sanctified KA. Nichol's periphrastic commentating, "the Egyptian ... soul," consolidates the recuperative transition from Kaka to KA, to ensure we're not left with, say, half a shit. 
This instance of immanent recuperation typifies the manner in which The Martyrology's paragrammatic error is qualified by a revelatory logic. Frank Davey identifies as a crisis in the 'play' of the poem this exegetical dynamic, through which the idea of the sign as manipulated by a writer is overwhelmed by a notion of originary truths. I suggest that the recurrent scenario of unmotivated, 'erroneous' fragments being sublimated into revealed truths offers some pretty heady possibilities for that purportedly defabricated" ' $i$ '. What are the implications, for instance, of truth-value circulating through the following section?

he/i/she

(why is the s the

feminizer?, makes the $i$ is, births it, gives it

its being, carries the he in the body of its word,

the men inside women...

(The Martyrology Book 4)

Wordplay is not framed here as a critique of how gender bias is encoded in and by language; it unravels, instead, the truths of sexual difference as revealed by the Word.

If Nichol's paragrammatic ruptures do not demonstrate his fidelity to the syntactical and lexical integrity of language, they do display his faith in language. Compare his discovery of how the feminizing ' $s$ ' "births" ' $\mathrm{i}$ ' with Marlatt's question in "Musing with Mothertongue," "what syntax can carry the turning herself inside out in love when she is both sucking mouth and hot gush on her lover's tongue?" (48). While linguistic schemata are challenged by both poets - in Nichol through mock etymology, in Marlatt through explicit critique-Marlatt's challenge extends to the value system permeating language, a system which remains unquestioned in Nichol. Alongside Nichol's passage, Marlatt's own meditation on a feminizing 's' in "Character" ("s / he: / s plural in excess of he" [Salvage 105]), offered in a context of exploration, rather than exegesis, appears at once strikingly 'intentional' and strikingly provisional. This complex textual effect is characteristic of experimental poets whose bodies do not adequate the white, male, heterosexual Subject that language presumes, who do not, in other words, operate on faith. Brossard does share Nichol's exegetical discourse to some extent; a self-proclaimed "zealot" (CBC interview, June 1995), she hopes "that by playing with language it will reveal unknown dimensions of reality" (73). Her revelations, however, are consistently 
guided by her own active ludic disposition, her stance as "troublemaker" ("Poetic" 77). Nichol and Brossard could be said to inhabit, respectively, both contradictory inclinations of a poetics of délire as outlined by JeanJacques Lecercle; Nichol's work bears out Lecercle's notion that "in the case of délire, language is master" (9), whereas Brossard affirms a definition of délire as "a perversion which consists in interfering, or rather taking risks, with language" (16).

Risk is a term that I suggest circulates too easily within an experimental poetic which does not take into account the politics and history of its notion of the Subject. I argue for a motivated error because inviting the slips and connotations of a language invested with androcentric bias demands an active vigilance. "Digging in that field can be, for a creative woman, a mental health hazard" (75), warns Brossard, who stresses that she consequently maintains a relationship with language marked by "awareness, concentration, sharpness" (82). Marlatt insists that "there's always that element of doubt - where did those words come from?" ("Roots" 224). She raises this issue of doubt in a discussion held with her male contemporaries in 1980 (published in Credences as "The Roots of Present Writing"). Both Victor Coleman and bp Nichol offer unfortunate characterizations of Marlatt's watchful process; Coleman calls her process "refined," Nichol calls it "genteel," and both oppose it to "risk taking" (226-27). There seems to be a lack of acknowledgement, here, of how risk might figure differently among writers; recall Brossard's line "To write I am a woman is full of consequences" ("Poetic" 81). My discomfort with this discussion points to what I find lacking in McCaffery's essays: an articulation of the particularized sexual politics of experimental writing. Watchfulness and desire are not mutually exclusive in poets such as Brossard, but embrace each other in a complex ambivalent movement which is necessarily operant both in a restricted economy of language and where language is put "en jeu."

In mécanique jongleuse suivi de masculin grammaticale, Brossard's field of action is the interface between language and women's desiring bodies, a sexual, textual interlining of surfaces, contours, flow, energies, mechanics. One of her strategies in dealing with such an interface, where the risk of women's devaluation is everpresent, is to write paragrammatically, engaging 'detached letters' in a poetics through which words, phonemes and letters are reconfigured to produce new meaning. The following lines appear in the first poem of the sequence entitled "Énonciation (sic) Déformation Ludique": 
fleuve moulé dans l'encre calme

fleuve tel fauve et flore fl (63)

The fragment " $\mathrm{fl}$ " could be read to suggest a truncation, implying that "l'encre calme" (calm ink) proves incommensurable to the "fauve" (fierce) flow of female desire. That fierce flow, however, is not merely the object of representation in mécanique jongleuse; it is the motivating energy. Read in the full context of this book, a textual environment infused with the values of women's passion and of that passion's volcanic effect on language, " $\mathrm{fl}$ " opens out. A shocking blossom of potential " $\mathrm{fl}$ " words in the audacious space: flageoller (to tremble), flamboyer (to blaze), flirter (to flirt), flotter

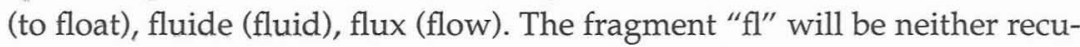
perated through monadic, transparent referentiality nor sublimated to an ancient god (as was kaka). Instead, this bit of waste, erroneous flotsam on the surface of signs, is left open to resignification.

"Masculin grammaticale," the poem sequence preceding "L'Énonciation," also deploys free letters, particularly in the third section. I present both stanzas in order to better demonstrate some of its intralinear play:

verte vague sur le ventre sur l'échine

fauche et frôle et somme le sexe d'

entame le souffle

sur-le-champ tout le parcours

jusqu'en la poitrine vague

flottante

la conséquence d'essouff d's

l'x du exe l'axe de plaisir

force la forme et le poids de l'ongle

sur l'épine de chair qui convient

sur la peau pour

un renversement d'allures vives vers

les herbes y rouler d'inclinaison

The first fragment we encounter is the " $\mathrm{d}^{\prime \prime}$ " at the end of line 2, a letter at large which is all the more scandalous because the substitution of " $\mathrm{d}^{\prime \prime}$ " for 'de,' the grammatical function of élision, is motivated by an inducement to collapse, rather than isolate, words. The next time " $\mathrm{d}^{\prime \prime}$ " appears, it intro- 
duces line 7's "essouff," a fragment implying the verb 'essoufler' which means 'to make breathless.' Line 7 whimsically demonstrates that losing letters is indeed "la conséquence" of getting short of breath, thus concretizing the thematic flow of breathless erotics in this poem. The truncation of "essouff" is underscored by the complete word "souffle" in line 3 (though the appearance of the verb "essouffle" minus its end does beg the question of whether the earlier "souffle" is in fact the same verb freed of its beginning. The e in line 3's "le" appears suddenly vulnerable to annexation). The " $\mathrm{d}$ " appears a third time - is " $\mathrm{d}$ " the shapely ideogram of "la poitrine vague / flottante" (the vague floating breast)? - at the end of line 7 , preceding the solo letter ' $s$ ' in "d's." "d's" repeats the first syllable of "d'essouff" phonetically and is followed by a structural analogue, " 1 ' $x$ "; both "d's" and "l' $x$ " are composed of individual letters sutured by an elisional apostrophe. That cluster running over into line 8 , "d's l'x du," is a resonant paragrammatical recombination of "le sexe $\mathrm{d}^{\prime \prime}$ " from line 2. " 1 ' $x^{\text {" }}$ itself undergoes a shift through "exe" to "l'axe." The fragment "exe" must have broken off of "sexe," a connection which would explain the appearance of that errant "s" from line 7, and would also bolster the proposition that the $x$ in "exe" is "l'axe de plaisir" (the axis of pleasure). Such a proposition is well supported within the charged graphic-thematic matrix of mécanique jongleuse. ' $\mathrm{X}$ ' clearly works well as an ideogram here; suggesting we view it as an axis inaugurates a fairly unproblematic transit into the undeniable materiality which, as this book attempts to show, is the common ground of the linguistic and the corporeal. ${ }^{8}$ But why, particularly, the ' $x$ ' in "exe"? If ' $x$ ' is an axis of pleasure in this figure, what or who are being pleasurably conjoined? Finding two 'e's straddling the $x$, my reading is necessarily inspired by the operation of the ' $e$ ' in Brossard's corpus. Her work has illuminated the already fetishized condition of ' $e$ ' as feminizer, shaken the grammatical regulation of its use, and spun ' $e$ ' into transgressive action. Such a transgression of grammatical gender is enacted in the title of this poem, "masculin grammaticale." If there is to be an axis of pleasure anywhere in language, it is not surprising that Brossard would choose to stage a hot time between two letter e's, two marks of the feminine, constructing a decidedly lesbian paragram.

Brossard's prose poem sequence, "Sous La Langue," published in a bilingual edition which offers French and English on facing pages, is driven in part by the energy of words within words and the flow of syllables repeated with change. The third stanzagraph concludes: 
Fricatelle ruisselle essentielle aime-t-elle le long de son corps la morsure, le bruit des vagues, aime-t-elle l'état du monde dans la flambée des chairs pendant que les secondes s'écoulent cyprine, lutines, marines.

Readers familiar with Brossard's work will notice the repeated feminizing word-end '-elle' gendering the first three words here, and will note too those letters' constitution of the pronoun 'elle' ('she'). The appearance of a fourth polysyllabic unit, "aime-t-elle," confirms this pronomial presence, as 'elle' is set off through hyphenation. The last few words here are also generated out of a process of syllabic repetition with change. The "s'éc" of "s'écoulent" is a transposition of the "sec" of "secondes." "Cyprine" is the hinge of this sequence; its first syllable carries over the unit of sibilant + vowel from the first two words, and initiates a run of homophonic endsyllables: cyprine, lutines, marines. "Cyprine," a word denoting female sexual secretions, does not appear in standard French dictionaries, although lesbian feminist writers have propelled it into literary circulation. Cyprine is met, in Susanne de Lotbinière-Harwood's translation, "Undertongue," by the even more scandalous term, "cyprin." The translator recalls her invention:

Over coffee with an Anglophone friend shortly before my deadline for the bilingual edition, I was talking about my on-going search for an English word for cyprine. "We have no word," she said, "no word but wet." Later, determined, I sat at my typewriter to stream-of-consciousness on it. Lo and behold, my unconscious yielded, and wrote: "...silken salty cyprin." There it was! So obvious, too obvious. (147)

What I find instructive in her account is an easy gathering together of seemingly contradictory motivations; she was "determined" to be receptive to what her "unconscious yielded." Here is the alchemy of intention and error which I read as desire. "Cyprin" is a complete innovation, an error in English which will not be left to waste, for it serves as corrective to a glaring 'error in English,' which is that there is "no word." "Too obvious," she says above, suggesting the force of grammatical discipline and the layers of misogynist bias which keep the obvious from view.

In his Martyrology, bp Nichol persistently transgresses a restricted economy of writing through his playful mobilization of the concrete resources 
of language. What I have tried to show here is that his equally persistent recuperations back into that economy, as well as McCaffery's characterizations of this retreat as a "territorializing force," mark a particular interest in the integrity of a restricted economy, a realm lesbian paragrams unmask as one of devaluation and official feminine hygiene. Footnoting her neologism, de Lotbinière-Harwood states, "We are proposing cyprin for English usage." Her statement announces the value invested in this 'error' and the value invested, concomitantly, in the secretion itself. Letters and syllables which do not signify, fluids without a name, are rallied into a presence which can figure into the imagined contours and mechanics of female bodies. e and e. The paragram in a lesbian feminist text may indeed threaten the continuity of a normative model of subjectivity, but at the same time it functions as a "territorializing force," a ludic operation through which female desire opens language to female desire.

\section{Notes}

${ }^{1}$ In English: Daydream Mechanics, Trans. Larry Shouldice, Toronto: Coach House Quebec Translations, 1980. The final e muet of grammaticale marks an instance of subversive erroneous feminization; the term being modified is the otherwise unambiguous masculin. I use boldface here as a nod to L'Hexagone's cover, on which a black e stands out among the green letters of Brossard's title.

${ }^{2}$ Frank Davey attributes the popularity of Nichol's work partly to its elaboration of contemporary values: "friendship, family, community, ecology, world peace, the distortions of 'official histories'" (39).

${ }^{3}$ This is Leon S. Roudiez's translation of Pouvoirs de l'horreur, Éditions du Seuil, 1980.

4 See Shirley Neuman's essay "Autobiography, Bodies, Manhood" for an analysis of Barbin's Memoirs and the medical discourses constructing his masculinity.

${ }^{5}$ In 1985 NBJ and Writing presses in Montreal published Mauve and Jeu de Lettres, two chapbooks featuring the mutual translations or, as the publishers dubbed them, "transformances" of Brossard and Marlatt. Reprinted as "Acts of Passage" in Marlatt's Salvage (Red Deer College P, 1991).

${ }^{6}$ In 1984 Bob Perelman published a book of short prose pieces entitled a.k.a. 
7 "En jeu" is a phrase which recurs in Brossard's poetry (see mécanique jongleuse 48, and "Jeu de lettres," Salvage 110). It signifies doubly as 'at play' and 'at risk.'

${ }^{8}$ In his translation, Larry Shouldice highlights this shared materiality through a resource pertinent to this poem, yet particular to English. His version of lines 6 and 7 runs "breast / result of getting short of brea th's" (51). His shifting from "breast" into "brea th's" submits an affiliation between breast and breath, indexed by the shared 'brea,' which is etymologically errant, but somatically sound (breasts and breath originate from around the same neighbourhood of your body). An isolated 'brea' (or 'th's' or ' $\mathrm{fl}^{\prime}$ ' for that matter) on the page does not signify morphemically. This fragmentation effects a paragrammatic highlighting of materiality, which proposes a partial answer to the thorny problem of how language and female desire can get along. Rather than language standing for the body, the two can lie down and be contiguous.

\section{Works Cited}

Brossard, Nicole. Daydream Mechanics. Trans. Larry Shouldice. Toronto: Coach House Quebec Translations, 1974.

- mécanique jongleuse suivi de masculin grammaticale. Ottawa: Les Éditions de l'Hexagone, 1974.

-. "Poetic Politics." The Politics of Poetic Form. Ed. Charles Bernstein. New York: Roof Books, 1990. 73-86.

-. Sous La Langue / Under Tongue. Trans. Susanne de LotbinièreHarwood. Montréal and Charlottetown: L'Essentielle, éditrices and Gynergy Books, 1987.

Brossard, Nicole and Daphne Marlatt. "Acts of Passage." Salvage. By Daphne Marlatt. Red Deer: Red Deer College P, 1991. 93-110.

Davey, Frank. "Exegesis / Eggs à Jesus: The Martyrology as a Text in Crisis." Miki 38-51.

de Lotbinière-Harwood, Susanne. Re-Belle et Infidèle/ The Body Bilingual. Montréal and Toronto: Les éditions du remue-ménage / Women's Press, 1991.

Kristeva, Julia. Powers of Horror: An Essay on Abjection. Trans. Leon S. Roudiez. New York: Columbia U P, 1982.

Lecercle, Jean-Jacques. Philosophy Through the Looking Glass: Language, nonsense, desire. La Salle, Ill.: Open Court, 1985. 
Marlatt, Daphne. "musing with mothertongue." Tessera / Room of One's Own 8 (1984): 53-56.

-. Discussion participant. "The Roots of Present Writing." Credences 2.2/3 (1984): 229-36.

McCaffery, Steve. "The Martyrology as Paragram." North of Intention: Critical Writings, 1973-1986. New York: Roof Books, 1986. 58-76.

-. "Writing as a General Economy." North of Intention. 201-21.

Miki, Roy. "Reading ? Writing The Martyrology: An Introduction." Tracing the Paths: Reading ? Writing The Martyrology. Ed. Roy Miki. Vancouver: Talonbooks, 1983. 11-34.

Neuman, Shirley. "Autobiography, Bodies, Manhood." Autobiography and Questions of Gender. Ed. Shirley Neuman. Portland and London: Frank Cass, 1991. 137-65.

Nichol, bp. The Martyrology: Books 1 \& 2. Toronto: Coach House, 1977.

,. The Martyrology: Books 3 \& 4. Toronto: Coach House, 1976. 